\title{
Streptococcus lactarius sp. nov., isolated from breast milk of healthy women
}

\author{
Correspondence \\ Antonio Maldonado-Barragán \\ maldoantonio@gmail.com
}

\author{
Virginia Martín, ${ }^{1}$ Rosario Mañes-Lázaro, ${ }^{2}$ Juan Miguel Rodríguez ${ }^{1}$ \\ and Antonio Maldonado-Barragán ${ }^{1,3} \dagger$
}

\author{
${ }^{1}$ Departamento de Nutrición, Bromatología y Tecnología de los Alimentos, Universidad \\ Complutense de Madrid, 28040 Madrid, Spain \\ ${ }^{2}$ ENOLAB-Laboratorio de Microbiología Enológica, Departamento de Microbiología y Ecología, \\ Facultad de Biología, Universidad de Valencia, 46100 Burjassot, Valencia, Spain \\ ${ }^{3}$ Departamento de Biotecnología de Alimentos, Instituto de la Grasa, Consejo Superior de \\ Investigaciones Científicas, 41012 Sevilla, Spain
}

Breast milk is a source of commensal and potentially probiotic bacteria for the infant gut, including streptococci, staphylococci, bifidobacteria and lactic acid bacteria (Heikkilä \& Saris, 2003; Martín et al., 2003; Perez et al., 2007; Jiménez et al., 2008a). At the time of writing, the genus Streptococcus consisted of 109 species and 15 subspecies (DSMZ, 2010), most of them belonging to one of the six phylogenetic clusters that have been established based on 16S rRNA gene sequence analysis (Kawamura et al., 1995). Streptococci isolated from human colostrum or milk of healthy women usually belong to the Streptococcus salivarius (S. bovis, S. salivarius) or Streptococcus mitis (S. mitis, S. oralis, S. parasanguinis, S. infantis, S. peroris) groups, as determined by classical phenotypic characteristics and $16 \mathrm{~S}$ rRNA gene sequencing (Heikkilä \& Saris, 2003; Jiménez et al., 2008b; Marín et al., 2009). In addition, streptococcal DNA is also commonly detected in this biological fluid by using molecular techniques such as

†Present address: Departamento de Biotecnología de Alimentos, Instituto de la Grasa, Consejo Superior de Investigaciones Científicas, 41012 Sevilla, Spain.

The GenBank/EMBL/DDBJ accession numbers for the 16S rRNA and tuf gene sequences of strain $\mathrm{MV}^{\top}{ }^{\top}$ are GU045364 and GU045365, respectively.

A supplementary figure is available with the online version of this paper.
PCR-DGGE (Delgado et al., 2008) or quantitative real-time PCR (Collado et al., 2009).

The members of the mitis group, which includes 12 species (S. mitis, S. pneumoniae, S. pseudopneumoniae, S. oralis, S. infantis, S. australis, S. parasanguinis, S. sanguinis, S. gordonii, S. sinensis, S. cristatus and S. peroris), have traditionally caused considerable confusion for both clinical microbiologists and taxonomists (Facklam, 2002). They are difficult to identify by using biochemical tests due to a lack of reliable and updated biochemical traits (Kawamura et al., 1998). Furthermore, members of the mitis group are closely related to each other genetically, and it is very difficult to differentiate between them even by genetic methods, since some members display more than $99 \%$ 16S rRNA gene sequence similarity and show 40$60 \%$ DNA-DNA relatedness (Kawamura et al., 1995). However, sequencing of other housekeeping genes, such as $\operatorname{sod} A, r p o B$ or $t u f$, has provided useful tools for the identification of species within the genus Streptococcus and, in particular, within the mitis group (Poyart et al., 1998; Drancourt et al., 2004; Picard et al., 2004). Recently, Bishop et al. (2009) developed software based on multilocus sequence analysis and phylogenetic comparisons of seven housekeeping genes for the identification of viridans streptococci. The difficulties in achieving an accurate 
identification among the species of the mitis group may have practical consequences, since this group contains 11 species that are considered prototype commensals of the digestive and upper respiratory tracts, as well as one of the leading human pathogens (S. pneumoniae) (Kilian et al., 2008).

While assessing the bacterial diversity of breast milk from healthy woman (Martín et al., 2007; Jiménez et al., 2008a), we isolated streptococci that seemed to belong to the mitis group, but study of the phenotypic and genotypic characteristics and phylogenetic position of strains $M V 1^{\mathrm{T}}$, MV2 and MV3 indicated that these strains represented a novel species of the genus Streptococcus.

Isolates $\mathrm{MV}^{\mathrm{T}}$, MV2 and MV3 were isolated from breastmilk samples collected as described previously (Jiménez et al., 2008b), and each one was obtained from a different (and non-related) healthy woman. The samples had been inoculated on Columbia CNA agar plus $5 \%$ sheep blood, containing colistin and nalidixic acid (CNA; bioMérieux), under anaerobic conditions (MINI-MACS anaerobic workstation; DW Scientific) at $37^{\circ} \mathrm{C}$ for $48 \mathrm{~h}$. Preliminary $16 \mathrm{~S}$ rRNA gene sequence analysis ( $450 \mathrm{bp})$ of the three isolates by PCR amplification with primers plb16 (5'AGAGTTTGATCCTGGCTCAG- ${ }^{\prime}$ ) and mlb16 (5'-GGCTGCTGGCACGTAGTTAG-3') (Kullen et al., 2000) revealed very high similarity $(>98 \%)$ with a sequence from an uncultured Streptococcus clone.

To determine the phylogeny relationships of the three isolates, the 16S rRNA gene was amplified and sequenced with primers 7 for $\left(5^{\prime}\right.$-AGAGTTTGATYMTGGCTCAG-3') and 1510r (5'-TACGGYTACCTTGTTACGACTT-3') (Lane, 1991). In addition, partial amplification and sequencing (488 bp) of the tuf gene with primers TufStrep1 (5'GAAGAATTGCTTGAATTGGTTGAA- ${ }^{\prime}$ ) and Tu-Strep-R (5'-GGACGGTAGTTGTTGAAGAATGG-3') (Collado et al., 2009) was performed.

The DNA sequences of the 16S rRNA and tuf genes of the isolates were compared with those available in the NCBI by using the BLASTN algorithm (http://blast.ncbi.nlm.nih.gov/ Blast.cgi). DNA sequences belonging to type strains of the genus Streptococcus were obtained from the GenBank database (see Fig. 1 and Supplementary Fig. S1, available in IJSEM Online). These sequences were aligned by using the CLUSTAL $\mathrm{W}$ method (Thompson et al., 1994) with the MEGA 4 (version 4.0.2) software (Tamura et al., 2007). Phylogenetic trees were constructed based on the neighbour-joining method (Saitou \& Nei, 1987). Bootstrapping analysis (1000 replicates) was done to study the stability of the groupings.

The $\mathrm{G}+\mathrm{C}$ content of strain $\mathrm{MV1}^{\mathrm{T}}$ was determined by HPLC following the procedure of Mesbah et al. (1989). DNA-DNA hybridization experiments were performed by the chemiluminescent-haemagglutinin method as described by Urdiain et al. (2008) using genomic DNA of strains $\mathrm{MV}^{\mathrm{T}}, \mathrm{MV} 2$ and MV3 and of S. peroris DSM $12493^{\mathrm{T}}$ and $S$.

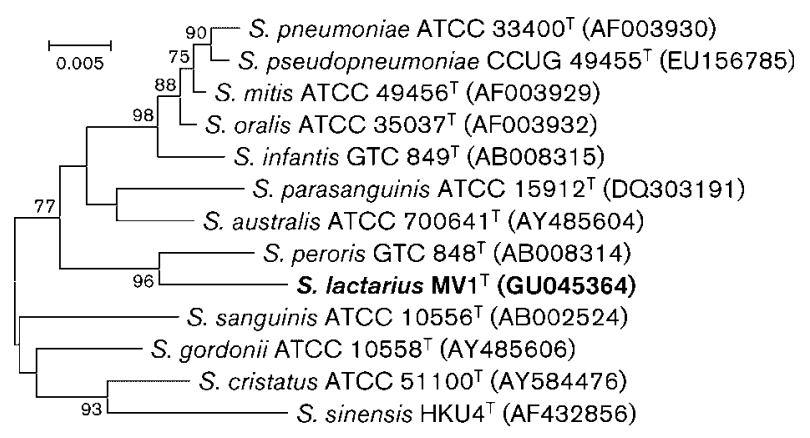

Fig. 1. Phylogenetic relationships of strain $M V 1^{\top}$ with members of the $S$. mitis group based on comparison of $16 S$ rRNA gene sequences (1452 nt). For clarity, isolates MV2 and MV3, which are $100 \%$ identical to $\mathrm{MV}_{1}{ }^{\top}$ in their $16 \mathrm{~S}$ rRNA gene sequences, are not shown. Nucleotide accession numbers are given in parentheses. The tree was based on the neighbour-joining method. Numbers on the tree indicate bootstrap values calculated for 1000 subsets for branch-points (values greater than $50 \%$ are shown). Bar, 0.005 changes per nucleotide position $(0.5 \%$ sequence divergence).

parasanguinis DSM $6778^{\mathrm{T}}$. The reference DNA was that of strain $\mathrm{MV1}^{\mathrm{T}}$, and the results are expressed as mean percentage values based on three independent hybridization experiments.

The 16S rRNA and tuf gene sequences of isolates $M V 1^{\mathrm{T}}$, MV2 and MV3 were $100 \%$ identical. BLAST analysis of the 16S rRNA gene sequences (1452 bp) showed 99.2\% similarity with sequences from uncultured clones assigned to the Lactobacillales and Streptococcus. The closest sequence corresponding to a defined species was that of S. peroris GTC $848^{\mathrm{T}}$, with a similarity of $98.2 \%$. Similarly, BLAST analysis of the partial sequence (488 bp) of the tuf gene showed $97.7 \%$ similarity with that of $S$. peroris CCUG $39814^{\mathrm{T}}$.

The phylogeny inferred from the 16S rRNA gene sequence using the neighbour-joining method showed that isolates $\mathrm{MV}^{\mathrm{T}}$, MV2 and MV3 formed a new subline within the Streptococcus species that make up the mitis group, being grouped with $S$. peroris GTC $848^{\mathrm{T}}$ (Fig. 1). Bootstrap resampling $(96 \%)$ showed that the strain $\mathrm{MV1}^{\mathrm{T}}$ and $S$. peroris GTC $848^{\mathrm{T}}$ branches were statistically significant. The phylogeny inferred from the tuf gene sequence showed a clustering of strain $\mathrm{MV}^{\mathrm{T}}$ and S. peroris CCUG $39814^{\mathrm{T}}$, with a bootstrap value of $98 \%$ (Supplementary Fig. S1). However, the topology of the tree was slightly different from that reconstructed with the 16S rRNA sequence. Therefore, sequences of the 16S rRNA and tuf genes (1940 nt) were concatenated. Phylogenetic trees inferred after compilation of the two sequences showed higher bootstrap support than individual phylogenetic analysis of the 16S rRNA and tuf genes (not shown).

Since the new taxon contains more than a single strain, and these strains share more than $97 \%$ 16S rRNA gene 
sequence similarity, DNA-DNA hybridization was carried following the recommendations of Tindall et al. (2010). Intraspecific hybridization assays, performed with strains $\mathrm{MV}^{\mathrm{T}}$, MV2 and MV3, gave values greater than $70 \%$, thus including these strains in the same genomic species (Stackebrandt \& Goebel, 1994; Stackebrandt \& Ebers, 2006). The relative binding ratios of strains MV2 and MV3 to strain $\mathrm{MV1}^{\mathrm{T}}$ were $98.7 \%( \pm 0.7 \%)$ and $92.9 \%$ $( \pm 0.8 \%)$, respectively. Interspecific hybridization of strain $\mathrm{MV}^{\mathrm{T}}$ with S. peroris DSM $12493^{\mathrm{T}}$ and S. parasanguinis DSM $6778^{\mathrm{T}}$ was $57.4 \%( \pm 0.1 \%)$ and $63.6 \%( \pm 0.7 \%)$, respectively. Reciprocal hybridization experiments using genomic DNA of S. peroris DSM $12493^{\mathrm{T}}$ as the template gave a value of $56.1 \%( \pm 1.0 \%)$ with strain $\mathrm{MV}^{\mathrm{T}}$. These results confirm that the three isolates $\mathrm{MV}^{\mathrm{T}}, \mathrm{MV} 2$ and MV3 represent a novel species. The $\mathrm{G}+\mathrm{C}$ content of strain $\mathrm{MV}^{\mathrm{T}}$ was $41.2 \mathrm{~mol} \%$.

Colonies of the novel strains grew on Columbia sheep- or horse-blood agar plates after 2 days of incubation. The colonies were about $0.3-0.5 \mathrm{~mm}$ in diameter, circular, flat, greyish with a smooth surface, non-pigmented and $\alpha$-haemolytic. However, under anaerobic conditions, haemolysis was visible only after the plates had been taken out of the anaerobic chamber for more than $1 \mathrm{~h}$. The cells were coccoid, usually occurring as pairs or short chains, Gram-positive after staining, non-spore-forming and nonmotile. They were facultatively anaerobic, but grew better under anaerobic conditions on CNA agar plates. The three strains showed a clumping phenotype when they were inoculated in brain heart infusion broth.

Substrate utilization, the fermentation/oxidation profile, acid production, activities of constitutive enzymes and some other physiological characteristics were examined using Rapid ID32 Strep and API ZYM strips (bioMérieux) according to the manufacturer's instructions. Being $\alpha$ haemolytic and negative in the Voges-Proskauer test (no production of acetoin), the novel taxon can be placed in the mitis group (Whiley \& Hardie, 2009). In addition, some of the results obtained using these phenotypic assays can be used to differentiate strains $M V 1^{\mathrm{T}}$, MV2 and MV3, which showed identical phenotypes, from closely related species belonging to the mitis group (Table 1). Using the Rapid ID32 Strep kit, the three strains produced a numerical profile of 74012601110 which, according to the manufacturer's database, corresponds to $S$. parasanguinis. Optochin sensitivity and bile solubility was tested as described previously (Whatmore et al., 2000), while latex agglutination was assessed using the Slide Pneumo kit (bioMérieux), which comprises a latex suspension sensitized with antisera to 83 pneumococcal capsular serotypes. The results, which were identical for strains $\mathrm{MV}^{\mathrm{T}}$, MV2 and MV3, are shown in Table 1.

Based on phenotypic, genotypic and phylogenetic characteristics, we suggest that the strains studied represent a novel species of the genus Streptococcus, for which the name Streptococcus lactarius sp. nov. is proposed.
Table 1. Biochemical characteristics that differentiate the novel strains from other members of the mitis group

Strains: 1, S. australis ATCC $700641^{\mathrm{T}}$; 2, S. peroris DSM $12493^{\mathrm{T}}$; 3, S. infantis ATCC $700779^{\mathrm{T}}$; 4, S. lactarius sp. nov. $\mathrm{MV1}^{\mathrm{T}}$ (strains MV2 and MV3 gave identical results); 5, S. oralis ATCC $35027^{\mathrm{T}}$; 6, S. sanguinis ATCC $10556^{\mathrm{T}} ; 7$, S. gordonii ATCC $10558^{\mathrm{T}} ; 8, \mathrm{~S}$. parasanguinis ATCC $15912^{\mathrm{T}}$; 9, S. cristatus ATCC $12479^{\mathrm{T}}$; 10, S. mitis ATCC $49456^{\mathrm{T}}$; 11, S. sinensis CCUG $48488^{\mathrm{T}}$. Results for $S$. peroris DSM $12493^{\mathrm{T}}$ and S. lactarius $\mathrm{MV1}^{\mathrm{T}}$ were determined in this study by using the Rapid ID 32 Strep kit under the same culture conditions. Data for other reference strains were taken from Willcox et al. (2001) and Hoshino et al. (2005). ND, No data available.

\begin{tabular}{|c|c|c|c|c|c|c|c|c|c|c|}
\hline Characteristic & 1 & 2 & 3 & 4 & 5 & 6 & 7 & 8 & 9 & 1011 \\
\hline \multicolumn{11}{|l|}{ Fermentation of: } \\
\hline Lactose & + & + & + & + & + & + & + & + & + & +- \\
\hline Trehalose & - & - & - & - & + & + & + & + & + & - \\
\hline Pullulan & + & - & + & - & - & + & - & - & - & +- \\
\hline Melibiose & - & - & - & - & - & - & - & + & - & -- \\
\hline $\begin{array}{l}\text { Methyl } \beta \text {-D- } \\
\text { glucopyranoside }\end{array}$ & - & - & - & - & - & - & + & - & - & -- \\
\hline Tagatose & - & - & - & - & - & - & + & + & - & -- \\
\hline \multicolumn{11}{|l|}{ Production of: } \\
\hline $\begin{array}{c}\beta \text {-Glucosidase } \\
\text { (aesculin) }\end{array}$ & - & - & - & + & - & + & + & + & - & -- \\
\hline$\alpha$-Galactosidase & - & - & - & - & - & - & - & + & - & +- \\
\hline Alkaline phosphatase & + & + & - & + & + & - & + & + & - & - \\
\hline$\beta$-Galactosidase & - & - & + & - & - & - & - & + & - & -- \\
\hline $\begin{array}{l}N \text {-Acetyl- } \beta \text { - } \\
\text { glucosaminidase }\end{array}$ & - & - & - & + & - & - & - & + & - & -- \\
\hline $\begin{array}{l}\text { Glycyl-tryptophan } \\
\text { arylamidase }\end{array}$ & + & - & + & + & + & + & - & + & + & +- \\
\hline$\beta$-Mannosidase & - & - & - & - & - & - & + & - & - & - \\
\hline Hydrolysis of arginine & + & - & - & + & - & + & + & + & + & -- \\
\hline Optochin sensitivity & $\mathrm{ND}$ & ND & ND & - & ND & ND & ND & ND & ND & $-\mathrm{ND}$ \\
\hline Bile solubility & ND & ND & ND & - & ND & ND & ND & ND & ND & $-\mathrm{ND}$ \\
\hline $\begin{array}{l}\text { Pneumococcal latex } \\
\text { agglutination }\end{array}$ & $\mathrm{ND}$ & $\mathrm{ND}$ & ND & - & ND & ND & ND & ND & ND & $-\mathrm{ND}$ \\
\hline
\end{tabular}

\section{Description of Streptococcus lactarius sp. nov.}

Streptococcus lactarius (lac.ta' ri.us. L. masc. adj. lactarius of or belonging to milk, referring to the isolation of the first strains from human breast milk).

Cells are Gram-positive after staining and are non-motile, non-spore-forming cocci, $1.0-1.3 \mu \mathrm{m}$ in diameter, occurring as pairs or short chains. Colonies on Columbia sheepor horse-blood agar plates after 2 days of incubation are about $0.3-0.5 \mathrm{~mm}$ in diameter, circular, flat, greyish, nonpigmented and $\alpha$-haemolytic. Grows under aerobic or anaerobic conditions but, under anaerobic conditions, haemolysis is visible only when the plates have been taken out of the anaerobic chamber for more than $1 \mathrm{~h}$. Hydrolyses hippurate. Voges-Proskauer-negative. Exhibits the following enzyme activities: arginine dihydrolase, $\beta$-glucosidase, alkaline phosphatase, alanine phenylalanine proline arylamidase and glycyl tryptophan arylamidase. 
Lacks $\beta$-glucuronidase, $\alpha$-galactosidase, pyrrolidonyl arylamidase, $N$-acetyl- $\beta$-glucosaminidase and $\beta$-mannosidase activities. $\beta$-Galactosidase activity is detected using $p$ nitrophenyl $\beta$-D-galactopyranoside as the substrate, but not with 2-naphthyl $\beta$-D-galactopyranoside. Positive for aesculin hydrolysis. Acid is produced from lactose, maltose and sucrose, but not from ribose, mannitol, sorbitol, trehalose, raffinose, glycogen, pullulan, melibiose, tagatose, melezitose, L-arabinose, D-arabitol, cyclodextrin or methyl $\beta$-Dglucopyranoside.

The type strain, $\mathrm{MV}^{\mathrm{T}}\left(=\mathrm{CECT} 7613^{\mathrm{T}}=\mathrm{DSM} 23027^{\mathrm{T}}\right)$, was isolated from breast milk of a healthy woman.

\section{Acknowledgements}

This work was supported by the FUN-C-FOOD (Consolider-Ingenio 2010) and AGL2007-62042 projects from the Ministerio de Educación y Ciencia (Spain). We thank Esther Jiménez for her skilful assistance in the purification of genomic DNA of S. lactarius strains.

\section{References}

Bishop, C. J., Aanensen, D. M., Jordan, G. E., Kilian, M., Hanage, W. P. \& Spratt, B. G. (2009). Assigning strains to bacterial species via the internet. BMC Biol 7, 3.

Collado, M. C., Delgado, S., Maldonado, A. \& Rodriguez, J. M. (2009). Assessment of the bacterial diversity of breast milk of healthy women by quantitative real-time PCR. Lett Appl Microbiol 48, 523-528.

Delgado, S., Arroyo, R., Martín, R. \& Rodríguez, J. M. (2008). PCRDGGE assessment of the bacterial diversity of breast milk in women with lactational infectious mastitis. BMC Infect Dis 8, 51 .

Drancourt, M., Roux, V., Fournier, P. E. \& Raoult, D. (2004). $r p o B$ gene sequence-based identification of aerobic Gram-positive cocci of the genera Streptococcus, Enterococcus, Gemella, Abiotrophia, and Granulicatella. JClin Microbiol 42, 497-504.

DSMZ (2010). Bacterial nomenclature up-to-date. http://www.dsmz. de/microorganisms/main.php?contentleft_id=14

Facklam, R. (2002). What happened to the streptococci: overview of taxonomic and nomenclature changes. Clin Microbiol Rev 15, 613630.

Heikkilä, M. P. \& Saris, P. E. J. (2003). Inhibition of Staphylococcus aureus by the commensal bacteria of human milk. J Appl Microbiol 95 , 471-478.

Hoshino, T., Fujiwara, T. \& Kilian, M. (2005). Use of phylogenetic and phenotypic analyses to identify nonhemolytic streptococci isolated from bacteremic patients. J Clin Microbiol 43, 6073-6085.

Jiménez, E., Delgado, S., Maldonado, A., Arroyo, R., Albújar, M., Garcia, N., Jariod, M., Fernández, L., Gómez, A. \& Rodríguez, J. M. (2008a). Staphylococcus epidermidis: a differential trait of the fecal microbiota of breast-fed infants. BMC Microbiol 8, 143.

Jiménez, E., Delgado, S., Fernández, L., Garcia, N., Albújar, M., Gómez, A. \& Rodríguez, J. M. (2008b). Assessment of the bacterial diversity of human colostrum and screening of staphylococcal and enterococcal populations for potential virulence factors. Res Microbiol 159, 595-601.

Kawamura, Y., Hou, X. G., Sultana, F., Miura, H. \& Ezaki, T. (1995). Determination of $16 \mathrm{~S}$ rRNA sequences of Streptococcus mitis and Streptococcus gordonii and phylogenetic relationships among members of the genus Streptococcus. Int J Syst Bacteriol 45, 406-408.
Kawamura, Y., Hou, X. G., Todome, Y., Sultana, F., Hirose, K., Shu, S. E., Ezaki, T. \& Ohkuni, H. (1998). Streptococcus peroris sp. nov. and Streptococcus infantis sp. nov., new members of the Streptococcus mitis group, isolated from human clinical specimens. Int J Syst Bacteriol 48, 921-927.

Kilian, M., Poulsen, K., Blomqvist, T., Håvarstein, L. S., BekThomsen, M., Tettelin, H. \& Sørensen, U. B. S. (2008). Evolution of Streptococcus pneumoniae and its close commensal relatives. PLoS ONE 3, e2683.

Kullen, M. J., Sanozky-Dawes, R. B., Crowell, D. C. \& Klaenhammer, T. R. (2000). Use of the DNA sequence of variable regions of the $16 \mathrm{~S}$ rRNA gene for rapid and accurate identification of bacteria in the Lactobacillus acidophilus complex. J Appl Microbiol 89, 511-516.

Lane, D. J. (1991). 16/23S rRNA sequencing. In Nucleic Acid Techniques in Bacterial Systematics, pp. 115-175. Edited by E. Stackebrandt \& M. Goodfellow. Chichester: Wiley.

Marín, M. L., Arroyo, R., Jiménez, E., Gómez, A., Fernández, L. \& Rodríguez, J. M. (2009). Cold storage of human milk: effect on its bacterial composition. J Pediatr Gastroenterol Nutr 49, 343-348.

Martín, R., Langa, S., Reviriego, C., Jiminez, E., Marin, M. L., Xaus, J., Fernández, L. \& Rodríguez, J. M. (2003). Human milk is a source of lactic acid bacteria for the infant gut. J Pediatr 143, 754-758.

Martín, R., Heilig, H. G., Zoetendal, E. G., Jiménez, E., Fernández, L., Smidt, H. \& Rodríguez, J. M. (2007). Cultivation-independent assessment of the bacterial diversity of breast milk among healthy women. Res Microbiol 158, 31-37.

Mesbah, M., Premachandran, U. \& Whitman, W. B. (1989). Precise measurement of the $\mathrm{G}+\mathrm{C}$ content of deoxyribonucleic acid by highperformance liquid chromatography. Int J Syst Bacteriol 39, 159-167.

Perez, P. F., Doré, J., Leclerc, M., Levenez, F., Benyacoub, J., Serrant, P., Segura-Roggero, I., Schiffrin, E. J. \& Donnet-Hughes, A. (2007). Bacterial imprinting of the neonatal immune system: lessons from maternal cells? Pediatrics 119, e724-e732.

Picard, F. J., Ke, D., Boudreau, D. K., Boissinot, M., Huletsky, A., Richard, D., Ouellette, M., Roy, P. H. \& Bergeron, M. G. (2004). Use of tuf sequences for genus-specific PCR detection and phylogenetic analysis of 28 streptococcal species. J Clin Microbiol 42, 3686-3695.

Poyart, C., Quesne, G., Coulon, S., Berche, P. \& Trieu-Cuot, P. (1998). Identification of streptococci to species level by sequencing the gene encoding the manganese-dependent superoxide dismutase. J Clin Microbiol 36, 41-47.

Saitou, N. \& Nei, M. (1987). The neighbor-joining method: a new method for reconstructing phylogenetic trees. Mol Biol Evol 4, 406-425.

Stackebrandt, E. \& Ebers, J. (2006). Taxonomic parameters revisited: tarnished gold standards. Microbiol Today 11, 152-155.

Stackebrandt, E. \& Goebel, B. M. (1994). Taxonomic note: a place for DNA-DNA reassociation and $16 \mathrm{~S}$ rRNA sequence analysis in the present species definition in bacteriology. Int J Syst Bacteriol 44, 846849.

Tamura, K., Dudley, J., Nei, M. \& Kumar, S. (2007). MEGA4: molecular evolutionary genetics analysis (MEGA) software version 4.0. Mol Biol Evol 24, 1596-1599.

Thompson, J. D., Higgins, D. G. \& Gibson, T. J. (1994). CLUSTAL W: improving the sensitivity of progressive multiple sequence alignment through sequence weighting, position-specific gap penalties and weight matrix choice. Nucleic Acids Res 22, 4673-4680.

Tindall, B. J., Rosselló-Móra, R., Busse, H.-J., Ludwig, W. \& Kämpfer, P. (2010). Notes on the characterization of prokaryote strains for taxonomic purposes. Int J Syst Evol Microbiol 60, 249-266.

Urdiain, M., López-López, A., Gonzalo, C., Busse, H.-J., Langer, S., Kämpfer, P. \& Rosselló-Móra, R. (2008). Reclassification of 
Rhodobium marinum and Rhodobium pfennigii as Afifella marina gen. nov. comb. nov. and Afifella pfennigii comb. nov., a new genus of photoheterotrophic alphaproteobacteria and emended descriptions of Rhodobium, Rhodobium orientis and Rhodobium gokarnense. Syst Appl Microbiol 31, 339-351.

Whatmore, A. M., Efstratiou, A., Pickerill, A. P., Broughton, K., Woodard, G., Sturgeon, D., George, R. \& Dowson, C. G. (2000). Genetic relationships between clinical isolates of Streptococcus pneumoniae, Streptococcus oralis, and Streptococcus mitis: characterization of "atypical" pneumococci and organisms allied to S. mitis harboring S. pneumoniae virulence factor-encoding genes. Infect Immun 68, 1374-1382.

Whiley, R. A. \& Hardie, J. M. (2009). Genus I. Streptococcus Rosenbach $1884,22^{\mathrm{AL}}$. In Bergey's Manual of Systematic Bacteriology, 2nd edn, vol. 3, pp. 655-711. Edited by P. De Vos, G. M. Garrity, D. Jones, N. R. Krieg, W. Ludwig, F. A. Rainey, K.-H. Schleifer \& W. B. Whitman. New York: Springer.

Willcox, M. D. P., Zhu, H. \& Knox, K. W. (2001). Streptococcus australis sp. nov., a novel oral streptococcus. Int J Syst Evol Microbiol 51, 12771281. 